\title{
Study on the Dilemma and Perfecting Path of Judicial Review of Administrative Agreements
}

\author{
Wei Li \\ Justice Department \\ Hainan Vocational College of Political Science and Law \\ Haikou, China 571100
}

\begin{abstract}
Administrative agreement is a means by which the government implements administrative policy and achieves administrative objectives. Its fundamental purpose is to realize administration. The administrative agreement itself has the dual attribute of administrative and agreement. There is difficulty in distinguishing between administrative agreement and civil agreement. In the current administrative trial practice, a lawsuit only examines an administrative act, which generally does not examine the legitimacy of the relative behavior. Therefore, in the judicial practice, the judicial review object of the administrative agreement case is difficult to determine. The difficulty of the examination is difficult to grasp. And the administrative subject of the relief is not clear and other practical difficulties. Therefore, it is necessary to adopt the judicial review mode centered on the change of the legal relationship of the administrative agreement. The object of the review is not limited to an administrative act. All administrative acts that cause changes in the legal relationship between administrative agreements should be included in the scope of the review. There should be a review of the legitimacy of administrative action, rational review and breach of contract in order to better respond to the demands of the parties.
\end{abstract}

Keywords-Administrative agreement; Judicial review; Dimension

\section{INTRODUCTION}

Administrative agreement is the product of administrative democratization and rule of law. One of the basic ideas of modern administrative law is to guarantee the democracy in the administrative process through the system innovation. One of the basic ideas of modern administrative law is to ensure the democratic nature of the administrative process through the system innovation in order to realize the equality of the administrative subject and the administrative counterpart in the administrative legal relationship. The purpose is to establish a kind of administrative power and civil rights between the administrative power and the civil rights. Administrative agreement is also called "administrative contract". Administrative agreement is a way of exercising administrative authority and performing legal duties. The core of the administrative agreement is the administrative legal relationship. In essence, the administrative agreement embodies the administrative legal relationship between the administrative subject and the relative person. The purpose of the administrative agreement is to achieve the public interest or administrative management, and its content is mainly the rights and obligations of administrative law.

\section{DIFFERENCES BETWEEN ADMINISTRATIVE AGREEMENTS AND CIVIL AGREEMENTS}

\section{A. The Main Body of the Agreement}

The administrative agreement is the act of both the administrative subject and the relative person. The simple civil rights and obligations are in the category of civil legal relations, and it is not an administrative agreement. The prerequisite for the conclusion of an administrative agreement is that there must be the participation of the administrative body. One party to the administrative agreement must be the administrative subject. If there is no administrative body involved, there is no the administrative agreement. However, the administrative entity involved in the agreement is not an administrative agreement. This is not the fundamental difference between administrative agreement and civil agreement. Because in the market economy conditions, the administrative body can also be used as a civil subject to market transactions. The difference between an administrative agreement and a civil agreement needs to be combined with other criteria.

\section{B. The Rights and Obligations of the Agreement}

In the administrative agreement, the administrative body of the agreement matters are the right to punish the provisions of the law." In the place where the rule of law, the free exercise of power is hindered by rules that force the ruler to act in a certain way." According to the theoretical research and practice, the administrative contract must have a legal basis or a clear Legal authorization. If the administrative organ has no legal authority and signed an administrative agreement with the relative, it is beyond the authority. Similarly, the obligations of the parties in the administrative agreement also come from the provisions of the law. From the formal point of view, the administrative agreement is the agreed obligations of both parties, but in essence it is a legal obligation. In addition, the establishment of the administrative agreement, performance, change, termination are required to comply with the relevant administrative procedures. Administrative agreement is different from the civil agreement, the difference is that the parties to the administrative agreement rights and obligations are mostly derived from the provisions of the administrative law. The autonomy of the parties to the administrative agreement is regulated by law. The space of the autonomy of 
the parties is very limited. Therefore, the administrative agreement has the content of the rights and obligations of the administrative law, and its contents are mandatory. On the one hand, if the parties violate the contract, it will lead to violation of administrative law. $\mathrm{He}(\mathrm{She})$ will bear the administrative legal responsibility. On the other hand, in some cases, even if the relative does not agree to sign an administrative agreement, the administrative subject can still make a unilateral administrative act in accordance with the law, which can produce the same administrative legal relationship.In the field of private law, civil agreement applies the principle of autonomy. While, in the field of public law, the contents of the administrative agreement are subject to the mandatory regulation of the law.

\section{The Purpose of the Agreement}

The purpose of the administrative agreement between the executive and the counterpart is to achieve the public interest or the administrative objectives. Take the housing compensation contract as an example, for the signing of this matter, the administrative counterparts have no choice, even if he does not sign the contract, the executive can also be ruled by the form of mandatory administrative functions. The purpose of the agreement is to determine whether it is a standard of administrative agreement, but the distinction between administrative agreement and the core of civil agreement is the content of rights and obligations. Because the concept of public interest and administrative objectives are more abstract, its connotation and extension is not clear. And whether the content of rights and obligations with the nature of public law is easy to judge.

\section{THE REALISTIC DILEMMA OF JUDICIAL REVIEW OF ADMINISTRATIVE AGREEMENTS}

\section{A. The Object of Judicial Review Is Difficult to Determine}

Although the administrative agreement is a more flexible way of administration, the administrative body in the administrative agreement is exercised by the state's public power. Therefore, in the process of making, implementing, changing or ending the administrative agreement, it is often accompanied by a number of administrative acts by one or more administrative subjects. However, the current administrative trial practice carry out the "case of a suit" principle.In other words, in an administrative litigation case, the court only examines an administrative act. If the administrative counterpart or the interested party sues the administrative action made by the different administrative bodies, it must be sued separately.And even administrative counterparts sues a number of administrative acts made by the same administrative body, it also must also be sued separately. This leads to the difficulty of determining the object of judicial review in the case of administrative agreement.

\section{B. The Strength of the Judicial Review Is Difficult to Grasp}

Article 6 of the Administrative Procedure Law clearly stipulates that the people's court shall examine the administrative cases and whether the administrative acts are legally examined. This article establishes the principle of legality review. Article 70 and Article 77 provide for further expansion of the scope of the rationality review on the basis of adhering to the principle of legality review. These two articles extend the scope of the reasonable review of the original administrative procedural law from the review of "administrative penalties are unfair" to the "apparent misconduct" of all administrative acts.The administrative agreement is the agreement between the administrative subject and the relative person. Although there are public power factors, the rights and obligations of the parties are mostly derived from the law, and the autonomy of the mean is strictly limited by the law. However, there may be parties in the administrative agreement that do not violate the mandatory provisions of the law, that is, there may be a certain degree of autonomy of the parties. Although the administrative procedural law establishes the principle of legitimacy review and the principle of rationality review, it still can not cover the whole contents of the administrative agreement.

\section{The Relief Is Not Clear}

The administrative litigation shall be the subject matter of the parties, that is, the plaintiff of the administrative litigation can only be a citizen, a legal person or other organization. The defendant can only be the administrative subject, the parties to the litigation status can not be interchangeable. Administrative litigation generally only review the legitimacy of the administrative action of the prosecution, do not review the legitimacy of the behavior of administrative counterparts, which makes the administrative body can not through administrative litigation approach to relief.In this way, if the relative person does not fulfill the administrative agreement, the executive body requires the relative to continue to fulfill the agreement.Then what kind of way to carry out relief is an unclear question, which can not find the basis in the administrative procedure law.

\section{ON THE WAY OUT OF JUDICIAL REVIEW OF ADMINISTRATIVE AGREEMENTS}

\section{A. Clearly Review the Object}

The administrative subject can only enter into an agreement with the relative person within the scope of the statutory authority, and it can not obtain the power which the law and regulations do not give to it by virtue of its superior status, otherwise it is beyond the power.In the administrative agreement disputes, in addition to the administrative agreement there may be administrative penalties, administrative licensing, administrative coercion and other derivative administrative acts The current administrative trial is the "case of a case" principle. That is to say, in a litigation case, the court only review an administrative act, which can not meet the administrative agreement case judicial review needs. It is a practical solution to implement a review model centered on changes in the legal relationship between administrative agreements. On the one hand, the object of examination is not limited to an administrative act. Any administrative act that causes a change in the legal relationship between the administrative agreement is included in the scope of the review of the administrative agreement case in order to better respond to the substantive demands of the parties. On the other hand, in the dimensions of the review, the court should set up the administrative action of the administrative agreement to change the legal relationship between the administrative agreement and the legal action of the administrative agreement. In addition, Judicial review of 
administrative agreement cases should follow the principle of legality review of administrative action, and carry out rationality review and default review.

\section{B. Clear the Scope and Intensity of the Review}

In the administrative agreement, although the party autonomy is strictly regulated by the law, but there is also a certain degree of autonomy. The judicial organ shall recognize the agreement between the administrative body and the relative person that does not violate the laws and regulations and does not prejudice the public interest. Because the administrative litigation has the characteristics of public law, the administrative agreement should adhere to the principle of comprehensive review. However, if the plaintiff does not make a request, if the court does not involve the mandatory provisions of laws and regulations and the public interest, the court can not make a request for the plaintiff to make the decision. In addition, the court may apply civil legal norms when examining administrative agreement cases. As long as the civil legal norms do not violate the administrative law and administrative procedural law mandatory provisions. Of course, in the administrative litigation, the court needs to review the legitimacy of the administrative act according to the authority. The administrative agreement is not the same. It must not only meet the requirements of the administrative legal norms, but also meet the requirements of the corresponding civil legal norms.

\section{Clear the Remedies of the Parties}

Administrative procedural law has clearly defined the administrative agreement into the scope of administrative litigation. The executive power that exists in the administrative agreement does not change its own nature, and still has the characteristics of mandatory, unilateral and statutory. The unilateral privilege of the administrative subject in the administrative agreement is one of the administrative rights, and the administrative property is the first attribute of the administrative agreement. Public interest is a basic principle in public law. The administrative subject enjoys such power. It can change and terminate the contract unilaterally because of the public interest. Therefore, the administrative organ has the administrative advantages in the change and dismissal of the administrative contract. Administrative agreement is a way for administrative organs to carry out administrative management. In the course of supervising and managing the implementation of the agreement, in order to stop the parties from violating the law, to avoid harm or to control the danger, the administrative organ may impose a temporary restriction on the relative freedom of the relative person or the temporary control of the relative person's property in accordance with the law.

\section{Judicial Review of Specific Procedures}

- The filing phase only examines the formal elements, that is, whether the prosecution of the parties is in compliance with the statutory conditions. The courts need not review the legality, reasonableness and breach of contract of the administrative agreement.

- During the trial phase, the administrative agreement case should adhere to the principle of comprehensive review. The court has both a procedural review and a substantive review. The procedural review is a review of whether the plaintiff's suit is in compliance with the conditions of statutory prosecution and the conditions of the court's jurisdiction. The substantive examination is a review of the legitimacy, a rationality review and a default review. If the plaintiff is the administrative subject of unilateral change, the lifting of the agreement and other acts to bring a lawsuit, the court will have to examine whether the plaintiff exceeds the statutory time limit. If the plaintiff is not in accordance with the law to fulfill the implementation of the law, did not fulfill the agreement in accordance with the agreement to bring a lawsuit, the court should apply the provisions of civil law norms. Whether the administrative subject is legal, the court should focus on the review of the administrative body in dealing with administrative agreement matters with legal powers. Whether the relative person has the corresponding ability to act. Whether the contents of the administrative agreement conform to the provisions of laws and regulations, the court should examine whether the agreement violates the relevant prohibitions. The contents of the agreement should be fair, reasonable, not obvious or unfair.Of course, administrative agreements must follow the principle of due process.

- In the executive phase of the implementation of the agreement, the administrative body can implement their own or apply for court enforcement. If the executive authorities have no right to perform their own, they must apply for court enforcement.Since the enforcement of the administrative agreement will have a significant impact on the rights and interests of the relative person, the review of the non-litigation case of the administrative agreement should adhere to the principle of comprehensive examination, conduct the legitimacy review, the rationality review and the default review.

\section{CONCLUSION}

How to identify the administrative agreement directly determine whether the case belongs to the scope of administrative litigation. The new administrative procedural law clearly includes the administrative agreement case into the category of dispute resolution of administrative litigation. However, how to distinguish its public and private attribute in the judicial review, clarify its boundary and identify the type of litigation will determine the principle of judicial review and the relief procedure. At present, China's administrative agreement judicial review system has not yet formed a complete theoretical system. It is the future path of administrative agreement dispute settlement to clarify the boundary of administrative agreement, perfect its judicial review system and establish corresponding judicial review procedure.

\section{REFERENCES}

[1] Jianshun Yang, "Administrative regulation and rights protection" Beijing: China Renmin University Press, 2007, pp.395.

[2] Bixin Jiang, Fengyun Liang, "Interpretation and Application of Judicial Interpretation of New Administrative Litigation Law", Beijing: China University of Political Science and Law Press1999, pp.286. 
[3] Bodenheimer, “Jurisprudence - Philosophy of Law and Its”Beijing:China Legal Publishing House, 2015, pp.164-165.

[4] Yan Zheng, "The Application and Transcendence of Private Law Principle in Administrative Contract System", vol 4, Administrative law research, p.63.

[5] Jiejun Yang, "The Theory and Practice of Administrative Contract in China" Beijing:Law Publisher,2009, pp.90-99.

[6] Fengyun Liang, "Administrative agreement case hearing and judgment rules", vol 3, Journal of the National Academy of Public Prosecutors, p.54.

[7] Xujun Wang, "Judicial review of administrative contract",Beijing:Law Publisher, 2013, pp.132-139. 